Acta vet. scand. $1971,12,303-306$.

Brief Communication

\title{
IMMUNOFLUORESCENT IMMUNOGLOBULIN DIFFEREN- TIATION OF VIBRIO FETUS ANTIBODIES FROM BOVINE CERVICO-VAGINAL SECRETIONS
}

Reports on discrepancies between local and systemic immunily started to appear about 50 years ago (cf. Tomasi \& Bienenstock 1968). Protection against infections has been shown in many cases to be closely related to the antibody content of external secretions and more or less independent from the serum antibody level.

Three 18-24 months old heifers were inoculated in the cervical canal with material from a Vibrio fetus carrier bull. The heifers were tested bacteriologically according to Adler (1957) twice a week before and after inoculation. Nos. 7 and 75 were positive from days 11 and 7 respectively and onwards. No. 24 was constantly found non-infected. Mucus samples were collected by the tampon method (Szabo 1951). The proteins were eluted from the tampon with $5.0 \mathrm{ml}$ physiological saline buffered at $\mathrm{pH} 7.1$ by $0.01 \mathrm{M}$ phosphate (Nairn 1969). Approx. $2.5 \mathrm{ml}$ extract could be obtained after compressing the tampon with a spatula. The extract was centrifuged at $1800 \times \mathrm{g}$ for $20 \mathrm{~min}$., and the supernatant was subsequently filtered through $220 \mathrm{~nm}$ filters.

The antisera employed had all been exhaustively absorbed with Vibrio fetus organisms. The goat anti rabbit immunoglobulin had been rendered totally unreactive with bovine immunoglobulins by duplicate absorptions with bovine peripheral leukocytes isolated according to Aalund et al. (1970). Following the last absorption the fluoresceinisothiocyanate (FITC) labelled goat anti rabbit immunoglobulin (Behringwerke) was diluted 10 times, centrifuged at $40,000 \times$ g for $15 \mathrm{~min}$. and filtered through a $450 \mathrm{~nm}$ filter. All reagents were stored at $-20^{\circ} \mathrm{C}$ in $0.5 \mathrm{ml}$ aliquots.

Monospecific anti bovine IgG-1 and anti IgG-2 reagents were produced by immunizing rabbits with IgG-1 or IgG-2 and absorbing exhaustively with IgG-2 and IgG-1 respectively. Specific rabbit anti IgA and anti IgM were prepared according to Nansen et al. (1971).

Smears of Vibrio fetus were dried in the air and fixed in acetone for $10 \mathrm{~min}$. before examination with the immunofluorescence sandwich technique. This included subsequent reactions with tampon extract, rabbit anti bovine immunoglobulin and FITC labelled goat anti rabbit immunoglobulin. Each step of the reaction took place in a moist chamber at $37^{\circ} \mathrm{C}$ for $30 \mathrm{~min}$. Between the individual reactions 
the slides were rinsed thoroughly in phosphate buffered saline (Nairn). The cover slips were mounted in phosphate buffered glycerol (Nairn). The slides were examined in dark field illumination with a Zeiss WL microscope equipped with an FITC interference exciter

T a bl e 1. Immunofluorescent reactions.

\begin{tabular}{|c|c|c|c|c|c|c|}
\hline \multirow{2}{*}{$\begin{array}{r}\text { Time } \\
\text { (days) }\end{array}$} & & \multicolumn{5}{|c|}{ FITC-score } \\
\hline & & no. 7 & & no. 24 & & no. 75 \\
\hline-63 & 0 & & $\square$ & & $\square$ & \\
\hline-21 & $\square$ & & $\square$ & & 0 & \\
\hline $\left.0^{*}\right)$ & $\square$ & oestrus & $\square$ & & $\square$ & oestrus \\
\hline 4 & 0 & & 0 & oestrus & 0 & \\
\hline 7 & 0 & & 0 & & 0 & \\
\hline 10 & $\square$ & & $\square$ & & 0 & \\
\hline 14 & + & & + & & $\square$ & \\
\hline 18 & $\square$ & oestrus & $\square$ & & 0 & \\
\hline 21 & + & & ++ & & 0 & oestrus \\
\hline 25 & $\square$ & & $\square$ & & 0 & \\
\hline 27 & $\square$ & & 0 & oestrus & $\square$ & \\
\hline 28 & $\square$ & & $\square$ & & +++ & \\
\hline 30 & $+\overline{+}$ & & $\square$ & & $\square$ & \\
\hline 32 & $\square$ & & $\square$ & & ++ & \\
\hline 35 & $\square$ & & $\square$ & & ++ & \\
\hline 39 & +++ & oestrus & 0 & & 0 & \\
\hline 42 & ++++ & & 0 & & $\square$ & oestrus \\
\hline 46 & +++ & & 0 & oestrus & ++++ & \\
\hline 49 & ++ & & & & + & \\
\hline 53 & $\square$ & & & & +++ & \\
\hline 56 & +++ & & & & 0 & \\
\hline 60 & $\square$ & oestrus & & & +++ & \\
\hline 63 & ++++ & & & & 0 & oestrus \\
\hline 67 & ++++ & & & & +++ & \\
\hline 70 & & & & & +++ & \\
\hline 74 & & & & & +++ & \\
\hline 77 & & & & & 0 & \\
\hline 81 & & & & & ++++ & \\
\hline 84 & & & & & 0 & oestrus \\
\hline 88 & & & & & ++++ & \\
\hline 91 & & & & & +++ & \\
\hline 95 & & & & & ++++ & \\
\hline 97 & & & & & 0 & \\
\hline 109 & & & & & ++++ & \\
\hline 112 & & & & & + & \\
\hline 116 & & & & & +++ & \\
\hline
\end{tabular}

$\square=$ not done. *) day of inoculation. 
filter*), a $520 \mathrm{~nm}$ barrier filter and a high pressure 250 watt CSI halogen lamp. The fluorescence was scored + to ++++ according to the brightness of the FITC stained bacteria.

The results are given in Table 1 . Nos. 7 and 75 were negative prior to the inoculation. No. 24 was not tested prior to inoculation, but samples from days 4 and 7 were scored 0 . Nos. 7 and 24 had become positive at 14 days and no. 75 at 28 days. No. 7 remained positive during the entire observation period, while no. 75 was intermittently negative, to some extent synchronized with oestrus. No. 24 was reactive on days 14 and 21 .

Semiquantitative immunoglobulin differentiation on specimens from nos. 7 and 75 (Table 2) demonstrated that the antibody activity was almost equally distributed among the IgA, IgG-1 and IgM entities, while the IgG-2 activity was scored 0.

Table 2. Immunofluorescent immunoglobulin differentiation.

\begin{tabular}{|c|c|c|c|c|c|}
\hline \multirow{2}{*}{$\begin{array}{c}\text { Animal } \\
\text { no. }\end{array}$} & \multirow{2}{*}{$\begin{array}{l}\text { Time (days, } \\
\text { cf. Table 1) }\end{array}$} & \multicolumn{4}{|c|}{ FITC-score } \\
\hline & & IgA & IgG-1 & IgG-2 & IgM \\
\hline 7 & 63 & $++t+$ & ++ & 0 & +++ \\
\hline 75 & 46 & $+++t$ & ++++ & 0 & $++t$ \\
\hline
\end{tabular}

The results are consonant with the reports on IgA as the significant immunoglobulin in several secretions of many mammalian species. Wilkie (1970) has reported the exclusive occurrence of IgA mucus agglutinins following cervico-vaginal inoculation of heifers with Vibrio fetus. Contrasting our observations Wilkie found IgG and IgM mucus antibodies only after parenteral inoculation with Vibrio fetus. The results may encourage research on the possible application of this procedure to the diagnostics of Vibrio fetus infections.

\section{ACKNOWLEDGEMENT}

The authors are grateful to Hans Philipsen, D.V.M., Department of Obstetrics and Gynaecology, Royal Veterinary and Agricultural University, Copenhagen, for supplying the experimental material.

Knud Børge Pedersen*, Ole Aalund * , P. Nansen ${ }^{*}$ and H. C. Adler * The Department of Special Pathology and Therapeutics* and The Department of Forensic and State Veterinary Medicine**, Royal Veterinary and Agricultural University, Copenhagen, Denmark.

*) Laboratory of Technical Optics, Lynghy, Denmark. 


\section{REFERENCES}

Aalund, O., A. B. Hoerlein \& H. C. Adler: The migration test on circulating bovine leukocytes and its possible application in the diagnosis of Johne's disease. Acta vet. scand. 1970, 11, 331-334.

Adler, H. C.: Genital Vibriosis in the Bovine. Thesis. A/S Carl Fr. Mortensen, Copenhagen 1957.

Nairn, R. C.: Fluorescent Protein Tracing. 3rd Ed. E. \& S. Livingstone, Edinburgh and London 1969.

Nansen, P., T. Flagstad \& K. B. Pedersen: Preparation of antisera to bovine immunoglobulin classes by immunization with agar-gel precipitates. Acta path. microbiol. scand. 1971. In press.

Szabo, L.: Improved sampling method for demonstration of local antibodies in the vagina. Nature (Lond.) 1951, 168, 171-172.

Tomasi, T. B. \& J. Bienenstock: Secretory immunoglobulins. Advanc. Immunol. 1968, 9, 1-96.

Wilkie, B.: The immune response to genital infections. Symp. Bovine Immune System, The Interstate Inn, College Park, Maryland, USA 1970.

(Received April 28, 1971). 